\title{
Methanol and Ethanol Decomposition in Supercritical Water
}

\author{
By Walter Hack*, David A. Masten, and Steven J. Buelow \\ Photochemistry and Photophysics Group, CST-4, MS J567, Los Alamos National \\ Laboratory, Los Alamos, NM 87545, USA
}

Dedicated to Prof. Dr. Michael Buback on the occasion of his 60th birthday

(Received November 30, 2004; accepted December 16, 2004)

\section{Supercritical Water / Methanol Decomposition / Ethanol Decomposition / Kinetics / Chemical Waste}

The decomposition of $\mathrm{CH}_{3} \mathrm{OH}$ and $\mathrm{C}_{2} \mathrm{H}_{5} \mathrm{OH}$ in supercritical water was studied in a flow reactor tube $(\mathrm{Ni} / \mathrm{Mo} / \mathrm{Cr} / \mathrm{Fe}$ alloy) in the temperature range $597 \leq T / \mathrm{K} \leq 797$ at a pressure of $p=315$ bar for technical application of $\mathrm{scH}_{2} \mathrm{O}$ for hazardous chemical waste destruction. The $\mathrm{CH}_{3} \mathrm{OH}$ and $\mathrm{C}_{2} \mathrm{H}_{5} \mathrm{OH}$ concentrations in the liquid as a function of the residence times were determined by a Raman spectrometer.

The $\left[\mathrm{CH}_{3} \mathrm{OH}\right]$ and $\left[\mathrm{C}_{2} \mathrm{H}_{5} \mathrm{OH}\right]$ resp. decay followed first order kinetics and a rate constant $k_{1}(653 \mathrm{~K})=1.3 \times 10^{-2} \mathrm{~s}^{-1}$ for $\mathrm{CH}_{3} \mathrm{OH}$ and $k_{2}(653 \mathrm{~K})=5.5 \times 10^{-2} \mathrm{~s}^{-1}$ for $\mathrm{C}_{2} \mathrm{H}_{5} \mathrm{OH}$ was determined. The rate constant $k_{1}$ was found to be independent of the initial $\mathrm{CH}_{3} \mathrm{OH}$ concentration in the mass fraction range $0.002 \leq x_{\mathrm{m}} \leq 0.04$. The rate depended on the history of the reactor. Treatment with $\mathrm{NH}_{4} \mathrm{OH}, \mathrm{C}_{2} \mathrm{H}_{5} \mathrm{OH}$ or with $\mathrm{H}_{2} \mathrm{O}_{2}$ at $T=653 \mathrm{~K}$, did not change the rate. Treatment with $\mathrm{HNO}_{3} / \mathrm{H}_{2} \mathrm{O}_{2}$, however, at $T=838 \mathrm{~K}$ reduced the rate by about a factor of 1000 .

The Arrhenius-activation energy over the above temperature range was determined to be $E_{\mathrm{A}}=164 \mathrm{~kJ} / \mathrm{mol}$ for methanol and $E_{\mathrm{A}}=145 \mathrm{~kJ} / \mathrm{mol}$ for ethanol.

The major products from methanol decomposition were $\mathrm{CH}_{4}, \mathrm{H}_{2}$, and $\mathrm{CO}_{2}$ as observed by gas chromatography and $\mathrm{CH}_{4}$ and $\mathrm{CO}_{2}$ by FTIR-spectrometry. No other products were found. The products were not effected by the pretreatment of the reactor wall. A non-radical mechanism, which explains the formation of only these products, will be discussed.

\section{Introduction}

Supercritical fluids are emphasized to be advantageous as solvents for chemical reactions. They provide a continuously tunable temperature and pressure range

* Corresponding author. Permanent address: Max-Planck-Institut für biophysikalische Chemie, Am Faßberg 11, 37077 Göttingen, Germany. E-mail: whack@ gwdg.de 
and thus optimum reactivity and selectivity conditions may be chosen. The tunability of the reaction medium provides the potential of establishing suitable combinations of solvent and transport properties. As pointed out by Buback, it is possible to carry out chemical reactions by exploiting the special properties of the compressed fluid phase [1].

Supercritical water $\left(\mathrm{scH}_{2} \mathrm{O}\right)$ is an appropriate medium for the destruction of hazardous organic chemical waste. Partly oxidized hydrocarbons can be regarded as prototypes of such organic molecules the simplest of which is $\mathrm{CH}_{3} \mathrm{OH}$. For this reason the decomposition of methanol and ethanol is studied in sc water. In the gas phase, the decomposition of $\mathrm{CH}_{3} \mathrm{OH}$ has been studied extensively, whereby the excited $\mathrm{CH}_{3} \mathrm{OH}$ has been produced thermally in shock waves and flames, or chemically in the combination reaction $\mathrm{CH}_{3}+\mathrm{OH}$, or in other chemical reactions like $\mathrm{O}\left({ }^{1} \mathrm{D}\right)+\mathrm{CH}_{4}$ [2], or $\mathrm{CH}_{2}(\widetilde{\mathrm{a}})+\mathrm{H}_{2} \mathrm{O}$ [3]. For the gas phase at low densities the decomposition into two radicals

$$
\mathrm{CH}_{3} \mathrm{OH} \rightarrow \mathrm{CH}_{3}+\mathrm{OH}
$$

is well accepted as the dominant initial step [4] which proceeds with an activation energy of $E_{\mathrm{A}}=334 \mathrm{~kJ} / \mathrm{mol}$ [5]. This might be different at liquid-like densities realized in supercritical water and it seems to be interesting to study the $\mathrm{CH}_{3} \mathrm{OH}$ and $\mathrm{C}_{2} \mathrm{H}_{5} \mathrm{OH}$ decomposition under these conditions.

If supercritical water is used to destroy organic waste material, the small alcohols like methanol and ethanol might be regarded as a model compound to study the decomposition of $\mathrm{H} / \mathrm{C} / \mathrm{O}$ containing organic molecules. If water at high temperature and densities with significantly different physicochemical properties than $\mathrm{H}_{2} \mathrm{O}$ at low temperature and pressures, is used as a solvent for synthesis reactions or destruction reactions, it is essential to know the stability of the organic compounds. If decomposition under supercritical conditions cannot be avoided, it is necessary to know the decomposition products and the intermediated, i.e., the decomposition mechanism. For kinetic measurements also the decomposition rate has to be known. This study deals with some aspects with relevance to a technical and industrial use of $\mathrm{scH}_{2} \mathrm{O}$ for a realisation of hazardous chemical waste destruction.

The decomposition of methanol $[6,7]$ and ethanol $[8]$ in supercritical water have been studied with respect to the products, but no reaction rates were given. The decomposition of $\mathrm{CH}_{3} \mathrm{OH}$ in supercritical water was observed as a side effect, when oxidizing $\mathrm{CH}_{3} \mathrm{OH}$ either by $\mathrm{O}_{2}[9]$ or by $\mathrm{NO}_{3}{ }^{-}[10]$. The rate constant for the methanol decomposition at $T=817 \mathrm{~K}$ was found to be $k=3.1 \times 10^{-3} \mathrm{~s}^{-1}$ [9]. The products of the $\mathrm{CH}_{3} \mathrm{OH}$ decomposition were not reported. Moreover a slow hydro-thermolysis of methanol was observed in a static cell in supercritical water [7].

The aim of this work was to study the kinetics of the decomposition of $\mathrm{CH}_{3} \mathrm{OH} \rightarrow$ prod (1) and $\mathrm{C}_{2} \mathrm{H}_{5} \mathrm{OH} \rightarrow$ prod (2) in supercritical water, i.e.; to determine the rate, the activation energy, and the decomposition products. 


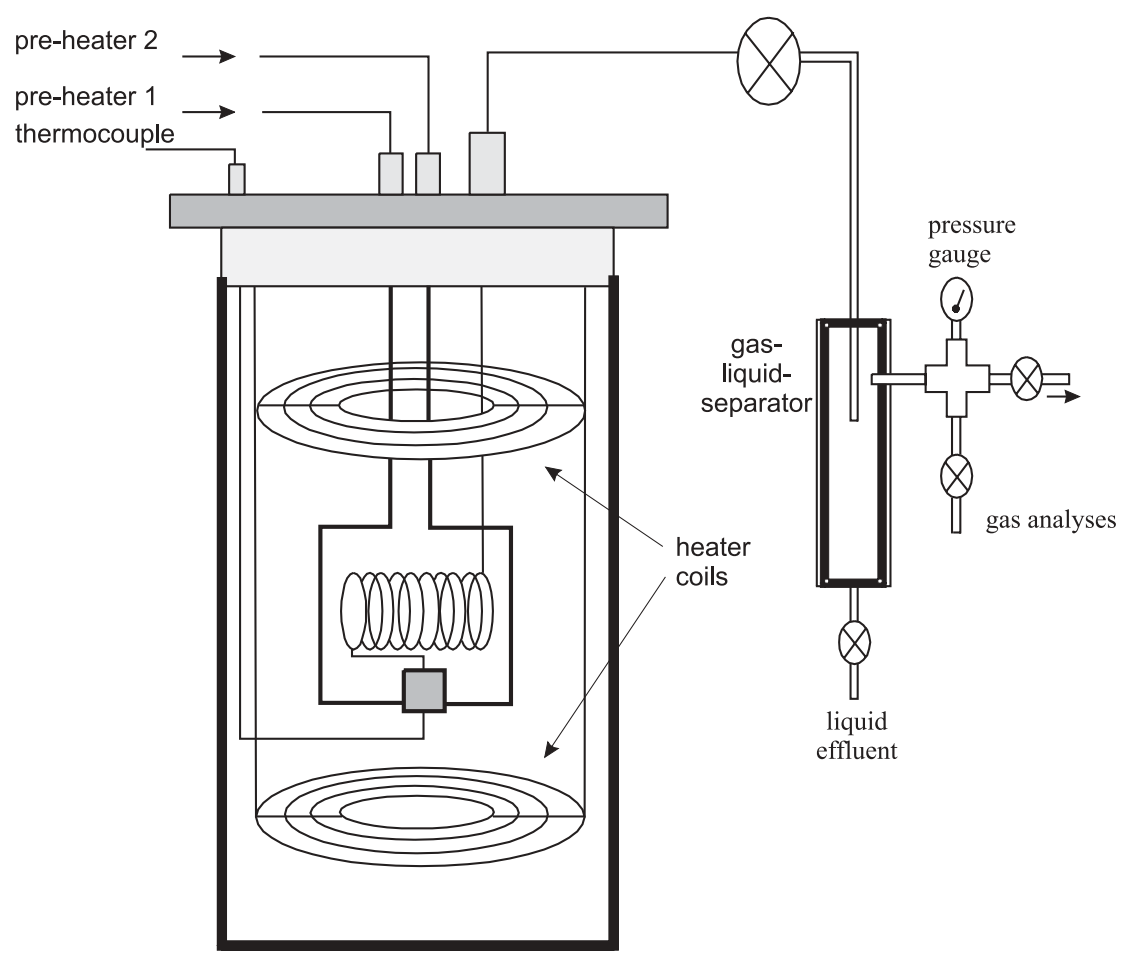

fluidized sand bath

Fig. 1. Experimental apparatus: Tubular reactor in a fluidized sandbath.

\section{Experimental}

The experiments were performed in a hastelloy tube flow reactor (alloy C-276 $(58 \% \mathrm{Ni} ; 16 \% \mathrm{Mo} ; 15 \% \mathrm{Cr} ; 5 \% \mathrm{Fe} ; 3.5 \% \mathrm{~W}$ and $2.5 \% \mathrm{Co})$ ). The tube had an inner diameter of $\varnothing=2.11 \mathrm{~mm}$. The reactor was heated in a fluidized sand bath as shown in Fig. 1 and described in detail in [10]. The liquid enters the reactor, which has a total volume of $V=12.17 \mathrm{ml}$ and a surface to volume ratio $S / V=1.9 \mathrm{~mm}^{-1}$, via one of two nearly symmetrical preheating tubes, which are connected to the flow reactor. At the end of the reactor there is a quenching section, which is cooled down to room temperature via water cooling. To study the reaction of two reactants, the mixing point (Fig. 1) is equivalent to reaction time zero. For a decomposition reaction, as studied in this work, the preheating time cannot be ignored. The volumes of preheating tubes are $V=6.8 \mathrm{ml}$ each. It was assumed that after approximately $30 \%$ of the preheating length, the final temperature can be attained taking into account the region in which the temperature changes from room temparature to reactor temperature. The effect of preheating can be changed by varying the residence time in the re- 
actor, pumping a constant amount of $\mathrm{CH}_{3} \mathrm{OH}$ solution through one preheating tube and pure water through the other. The results were less reliable due to the change in initial $\mathrm{CH}_{3} \mathrm{OH}$ concentration; but the above assumption could be verified. The uncertainty in the preheating section contributes to the uncertainty of the absolute value of the rate constant (see results section) but much less to the uncertainty of the activation energy.

The methanol/water and ethanol/water mixture was pumped into the reactor with two liquid chromatography feed pumps (Consta Metric 3200, LDC Analytical), which allowed a change of the total flow $(v)$ in the range of $0.05 \leq v / \mathrm{g} \mathrm{s}^{-1} \leq 0.358$. The flow was determined by measuring the mass decrease of the liquid reservoir or the mass of liquid leaving the reactor in a given time.

Probes from the liquid leaving the reactor were taken and analyzed by Raman spectroscopy. The Raman apparatus has been described in detail elsewhere [11]. The probe was excited with the $488 \mathrm{~nm}$ line of a cw-Ar ${ }^{+}-$laser, the scattered light red shifted by $2857 \mathrm{~cm}^{-1}$ was spectrally dispersed with a $0.6 \mathrm{~m}$ monochromator (Triplemate 1877 Spex Ind. Inc.) and detected with a CCD camera (ST-130 Princeton Instruments Inc.).

The gas products were analyzed either with a gas chromatograph (Hewlett Packard 5890 series II) or with an FTIR spectrometer (Perkin Elmer 1260X). The gas chromatograph was equipped with a capillary column (carboplat P 7 Chrom pak) and a thermal conductivity detector. Helium was used as a carrier gas, when $\mathrm{CO}_{2}, \mathrm{CO}, \mathrm{CH}_{4}$, and other hydrocarbons were to be detected; in an independent experiment $\mathrm{H}_{2}$ was detected with $\mathrm{Ar}$ as a carrier gas.

As reactants home-made de-ionized water was used and $\mathrm{CH}_{3} \mathrm{OH}(99.94 \%$ EM Science) with the main impurity being $\mathrm{H}_{2} \mathrm{O}(0.03 \%)$ and $\mathrm{C}_{2} \mathrm{H}_{5} \mathrm{OH}(99 \%$ EM Science) (impurity $\mathrm{H}_{2} \mathrm{O}$ ).

\section{Results}

\subsection{Reaction rate}

The rate constant for the reaction

$\mathrm{CH}_{3} \mathrm{OH} \rightarrow$ products

in water under liquid and supercritical conditions was measured in the temperature range $597 \leq T / \mathrm{K} \leq 719$. The initial concentration of $\mathrm{CH}_{3} \mathrm{OH}$ in water was varied in the range $0.002 \leq x_{\mathrm{m}} \leq 0.04$ (mass fraction) i.e. $0.001 \leq x \leq 0.0225$ (mole fraction). The pressure was kept in the region of $p=315$ bar. All experimental data are summarized in Table 1 . At $T \geq 797 \mathrm{~K}$ the reaction was found to be so fast that only a lower limit of the rate constant was determined.

The residence time in the reactor was varied by the pumping speed, which was limited to about $0.18 \mathrm{~g} \mathrm{~s}^{-1}$ for each pump. The residence time in the pre- 
Table 1. $\mathrm{CH}_{3} \mathrm{OH}$ decomposition. Experimental condition for all runs.

\begin{tabular}{lccccc}
\hline$T[\mathrm{~K}]$ & $P[$ bar $]$ & $\mathrm{CH}_{3} \mathrm{OH} \times 10^{-3}$ & $\rho\left(\mathrm{H}_{2} \mathrm{O}\right)\left[\frac{\mathrm{g}}{\mathrm{cm}^{3}}\right]$ & $\Delta t_{\mathrm{r}} \max [\mathrm{s}]$ & $k_{1}\left[10^{-3} \mathrm{~s}^{-1}\right]$ \\
\hline 597 & 313.2 & 5.87 & 0.716 & 244 & 1.3 \\
623 & 315.4 & 5.60 & 0.646 & 211 & 2.7 \\
653 & 312.5 & 1.25 & 0.543 & 199 & $13.0^{*}$ \\
653 & 313.9 & 1.47 & 0.543 & 179 & 14.6 \\
653 & 316.8 & 5.84 & 0.543 & 165 & 14.6 \\
653 & 316.0 & 23.1 & 0.543 & 181 & 11.2 \\
683 & 314.7 & 5.84 & 0.310 & 93.9 & 48.2 \\
719 & 315.8 & 5.77 & 0.165 & 21.6 & 200 \\
\hline
\end{tabular}

* surface oxidized by $\mathrm{H}_{2} \mathrm{O}_{2}$ treatment

heating tubes was taken into account by assuming that the final reactor temperature is reached after $30 \%$ of the preheating tube lengths. This assumption enters into the overall residence time and thus into the derived first order rate constant. The uncertainty of this assumption is responsible for the error bars given for the first order rate constant. The temperature dependence and thus the activation energy is much less effected by this correction.

The $\mathrm{CH}_{3} \mathrm{OH}$ concentration in the liquid samples collected at the end of the reactor was analyzed by a Raman spectrometer. The spectrometer gave a linear dependence for the Raman signal as a function of $\left[\mathrm{CH}_{3} \mathrm{OH}\right]$ for pure methanol samples. It has to be assumed that the Raman signal is not influenced by any of the products formed in the reaction. From the product analysis (see products) this assumption, however, appears valid.

The plots of $\ln \left\{\left[\mathrm{CH}_{3} \mathrm{OH}\right] /\left[\mathrm{CH}_{3} \mathrm{OH}\right]_{0}\right\}$ vs. residence times (whereby $\left[\mathrm{CH}_{3} \mathrm{OH}\right]$ is the $\mathrm{CH}_{3} \mathrm{OH}$ concentration at the exit and $\left[\mathrm{CH}_{3} \mathrm{OH}\right]_{0}$ the initial methanol concentration) yielded straight lines for all temperatures as shown in Fig. 2. From these data the rate constant at a given temperature, say $T=653 \mathrm{~K}$, was determined to be:

$$
k_{1}(653 \mathrm{~K})=(1.3 \pm 0.3) \times 10^{-2}\left[\mathrm{~s}^{-1}\right] .
$$

The error is mainly due to the uncertainty of the residence time.

The activation energy for the methanol depletion is obtained from a plot of $\ln k_{1}$ vs. $1 / T$ as shown in Fig. 3. A straight line is obtained, indicating an Arrhenius behaviour of the rate constant $k_{1}(T)$. The Arrhenius activation energy is found to be:

$$
E_{\mathrm{A}}=(167 \pm 20) \mathrm{kJ} / \mathrm{mol}
$$

in the temperature range $597 \leq T / \mathrm{K} \leq 719$. 


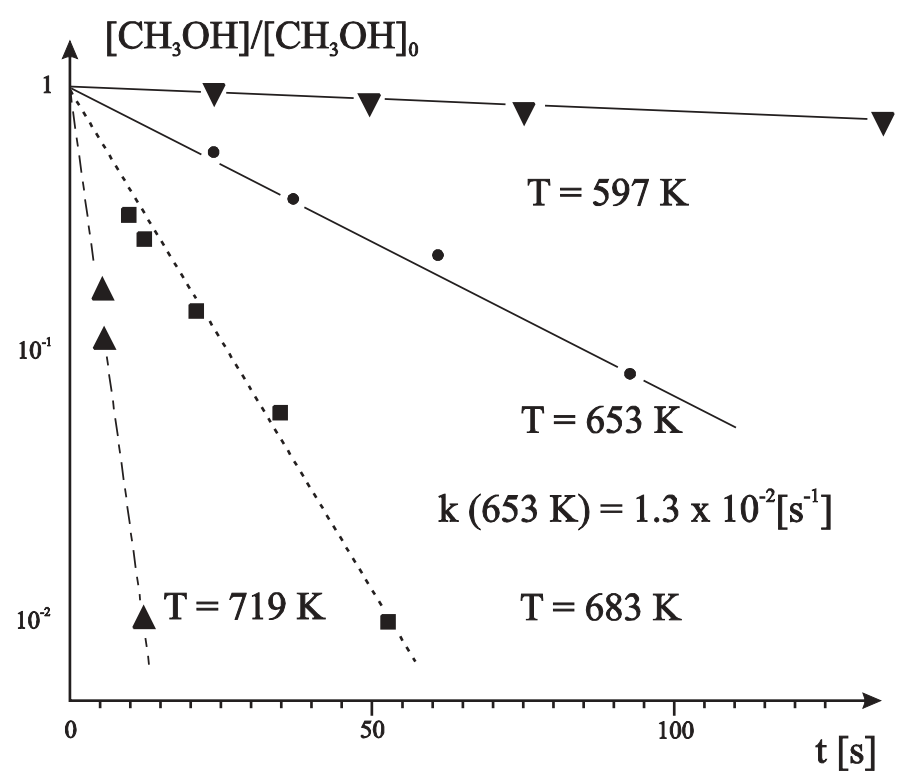

Fig. 2. First order decay of $\mathrm{CH}_{3} \mathrm{OH}$ with residence time at different temperatures.

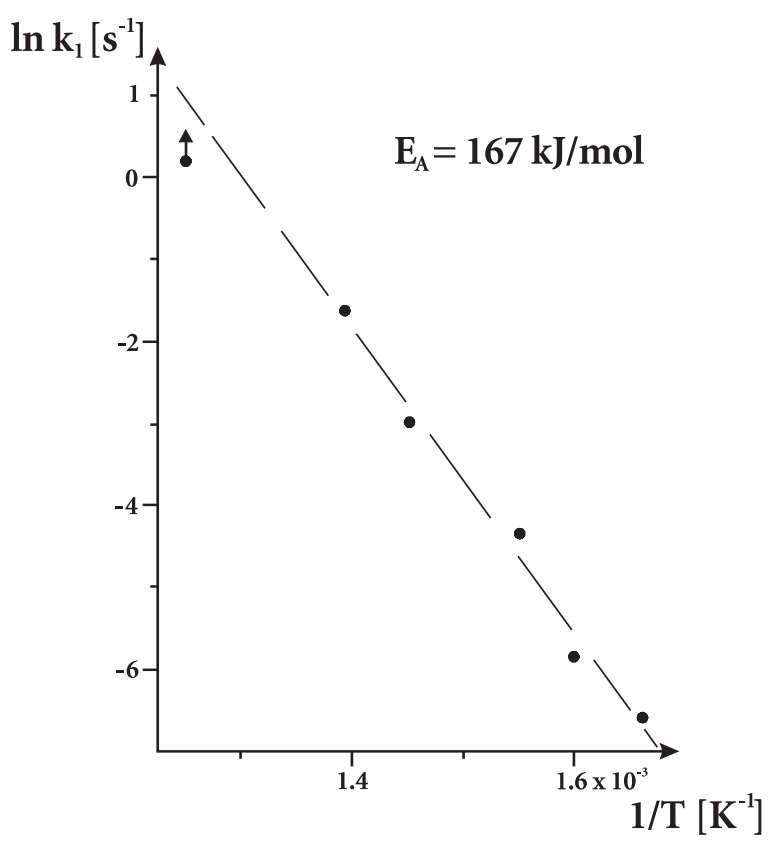

Fig. 3. Arrhenius plot for the methanol decomposition rate in supercritical water. The arrow indicates a lower limit at $k_{1}(789 \mathrm{~K})$. 
Table 2. $\mathrm{C}_{2} \mathrm{H}_{5} \mathrm{OH}$ decomposition. Experimental condition for all runs.

\begin{tabular}{lccccc}
\hline$T[\mathrm{~K}]$ & $P$ [bar $]$ & $\mathrm{CH}_{3} \mathrm{OH} \times 10^{-3}$ & $\rho\left(\mathrm{H}_{2} \mathrm{O}\right)\left[\frac{\mathrm{g}}{\mathrm{cm}^{3}}\right]$ & $\Delta t_{\mathrm{r}} \max [\mathrm{s}]$ & $k_{2}\left[10^{-3} \mathrm{~s}^{-1}\right]$ \\
\hline 597 & 312.3 & 4.059 & 0.716 & 106.9 & 5.9 \\
623 & 313.7 & 4.059 & 0.646 & 184.2 & 13.5 \\
653 & 316.1 & 4.059 & 0.543 & 158.6 & 55.5 \\
683 & 308.6 & 4.049 & 0.31 & 48.3 & 200 \\
719 & 315.7 & 4.04 & 0.165 & 8.5 & 600 \\
\hline
\end{tabular}

For one temperature $(T=653 \mathrm{~K})$ the initial concentration of $\mathrm{CH}_{3} \mathrm{OH}$ was varied from $x=1.42 \times 10^{-3}$ to $x=2.3 \times 10^{-2}$; no effect of $\left[\mathrm{CH}_{3} \mathrm{OH}\right]_{0}$ on the rate constant was observed, which indicated that none of the initially formed products seem to react further with $\mathrm{CH}_{3} \mathrm{OH}$ (see discussion).

For the reaction:

$$
\mathrm{C}_{2} \mathrm{H}_{5} \mathrm{OH} \rightarrow \text { products }
$$

the rate constant was measured in the temperature range $597 \leq T / \mathrm{K} \leq 719$. The experimental details are summarized in Table 2 . The initial concentration was given as the mole fraction $x=4.0 \times 10^{-3}$. The rate constant is about a factor of four higher than the rate constant of the decomposition of methanol at the same temperature, e.g.

$$
k_{2}(653 \mathrm{~K})=(55 \pm 13) \times 10^{-3} \mathrm{~s}^{-1} .
$$

The rate constant increases with increasing temperature. The temperature dependence is shown in Fig. 4. An Arrhenius plot leads to a straight line and can be described by an activation energy of

$$
E_{\mathrm{A}}=(145 \pm 15) \mathrm{kJ} / \mathrm{mol}
$$

in the studied temperature range. This means that the rate for ethanol is faster than for methanol but with a smaller temperature dependence in the given temperature range.

\subsection{Reaction products}

The reaction products of the methanol decomposition were detected by gas chromatography and by FTIR spectrometry in the gas phase obtained in a gas liquid separator behind the quenching section. The liquid was analyzed for products by gas chromatography and liquid chromatography.

The amount of gas produced was determined by the pressure increase in a known volume in a given time. 


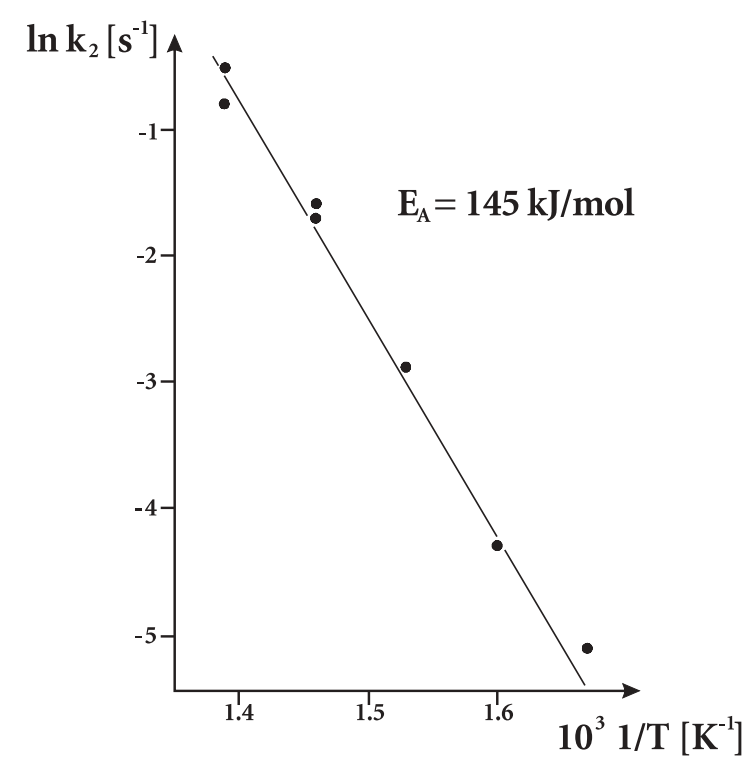

Fig. 4. Arrhenius plot for the ethanol decomposition rate in supercritical water.

The gas at a reactor temperature of $T=653 \mathrm{~K}$ consists mainly of $\mathrm{H}_{2}$ $\left(x_{\mathrm{H}_{2}}=0.5\right)$. The carbon is found as $\mathrm{CH}_{4}\left(x_{\mathrm{CH}_{4}}=0.33\right)$ and $\mathrm{CO}_{2}\left(x_{\mathrm{CO}_{2}}=0.12\right)$. The carbon balance was measured to be $94 \%$, i.e., more than $90 \%$ of the carbon initially bound in the $\mathrm{CH}_{3} \mathrm{OH}$ is found as $\mathrm{CH}_{4}$ or $\mathrm{CO}_{2}$. The gas product composition changes with temperature. At $T=797 \mathrm{~K}$, the methane concentration is significantly lower $\left(x_{\mathrm{CH}_{4}}=2 \times 10^{-3}\right)$ than at $T=653 \mathrm{~K}$, whereas the mole fraction of $\mathrm{H}_{2}$ is up to $x_{\mathrm{H}_{2}}=0.68$ and that of $\mathrm{CO}_{2}$ to $x_{\mathrm{CO}_{2}}=0.32$ when the temperature was changed from $T=653 \mathrm{~K}$ to $T=797 \mathrm{~K}$.

With the FTIR-spectrometer no further products were detected in the gas phase; in particular, no $\mathrm{C}_{2}$-containing compounds and no $\mathrm{CO}$ were found. In the liquid phase (at $T=653 \mathrm{~K}$ ) $\mathrm{CHOOH}$ was detected. The detection method was not calibrated for $\mathrm{CHOOH}$ but the amount of $\mathrm{CHOOH}$ was small (estimation $[\mathrm{CHOOH}] /\left[\mathrm{CH}_{3} \mathrm{OH}\right]_{0} \cong 2 \times 10^{-4}$ ).

\subsection{Reaction mechanism}

Several experiments were done to determine the reaction mechanism and its dependence on the pretreatment of the wall.

The reaction was followed at very low initial $\mathrm{CH}_{3} \mathrm{OH}$ concentrations and the reactor walls were treated in different ways by ethanol, hydrogen peroxide, and finally, by nitric acid/hydrogen peroxide.

It was observed that at the very low initial $\mathrm{CH}_{3} \mathrm{OH}$ concentrations $\left(x_{\mathrm{CH}_{3} \mathrm{OH}} \leq 5.25 \times 10^{-5}\right)$ the depletion rate was significantly lower than at higher 


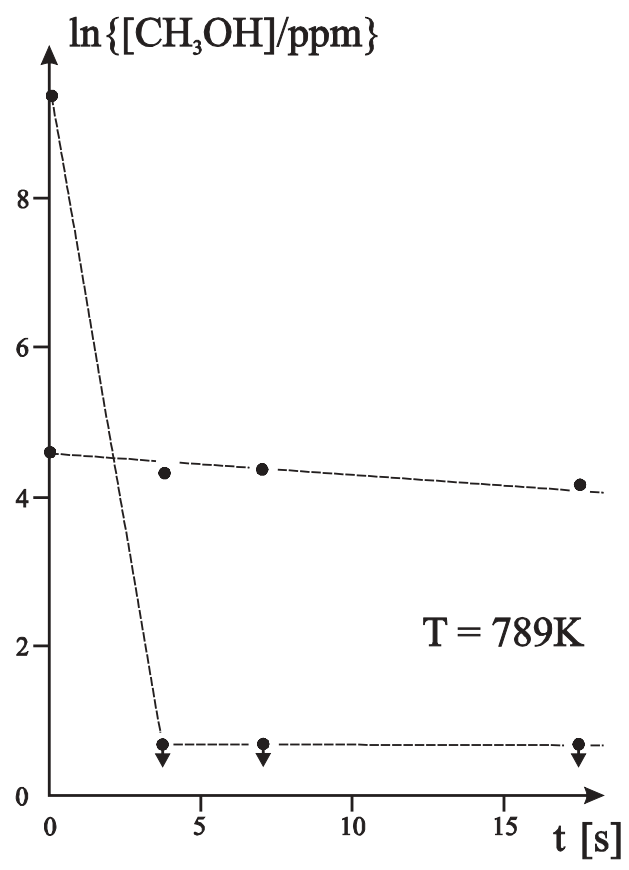

Fig. 5. Concentration profiles for $\mathrm{CH}_{3} \mathrm{OH}$ at $T=789 \mathrm{~K}, p=316.5$ bar (the straight lines are given to help to identify the measured points). $\downarrow=\mathrm{CH}_{3} \mathrm{OH}$ concentration below detection limit.

concentrations. At a temperature of $T=798 \mathrm{~K}$ the $\mathrm{CH}_{3} \mathrm{OH}$ concentration depleted to about $60 \%$ after the reaction time of $17 \mathrm{~s}$. This observation is interpreted as a surface reaction, i.e., $\mathrm{CH}_{3} \mathrm{OH}(\mathrm{aq})$ reacts with $\mathrm{CH}_{3} \mathrm{OH}(\mathrm{ad})$ (see discussion). The concentration-time profiles for an experiment with a high and a low initial concentration are shown in Fig. 5. The $\mathrm{CH}_{3} \mathrm{OH}$ concentration drops below the detection limit within several seconds (in agreement with the lower limit of the rate constant given in Fig. 3) when starting with high $\mathrm{CH}_{3} \mathrm{OH}$ initial concentrations. In the experiment with the low $\left[\mathrm{CH}_{3} \mathrm{OH}\right]_{0}$ value, the depletion of $\mathrm{CH}_{3} \mathrm{OH}$ is much slower and the $\mathrm{CH}_{3} \mathrm{OH}$ concentration stays at a much higher level. This behaviour is also explained by a heterogeneous mechanism (see discussion).

In order to study the surface effect on the rate constant, the reactor was treated with $\mathrm{C}_{2} \mathrm{H}_{5} \mathrm{OH}$ at temperatures up to $T=673 \mathrm{~K}$ for several hours before these measurements were done. For one experiment (see Table 1), the reactor was treated with $\mathrm{H}_{2} \mathrm{O}_{2}$ to oxidize the surface. The $\mathrm{H}_{2} \mathrm{O}_{2}$ (3 mass-\% solution in $\mathrm{H}_{2} \mathrm{O}$ ) was pumped through the reactor for two hours at $T=473 \mathrm{~K}$ and than for more than 4 hours at $T=573 \mathrm{~K}$ at a pressure of $p \cong 300$ bar. After that, the reactor was left at room temperature filled with $\mathrm{H}_{2} \mathrm{O}_{2}$ solution, for more than a day. Before starting the experiment, the reactor was rinsed with 
pure $\mathrm{H}_{2} \mathrm{O}$ at $T=653 \mathrm{~K}$. The rate constant for the methanol decomposition obtained after that treatment of the surface did not differ from the rate constants obtained under otherwise identical conditions (see Table 1). The reactor was heated with a solution of $\mathrm{HNO}_{3}$ and $\mathrm{H}_{2} \mathrm{O}_{2}$ (1 molar each) at $T=838 \mathrm{~K}$ for about $1 / 2 \mathrm{~h}$. After the treatment the reactor was rinsed with $\mathrm{H}_{2} \mathrm{O}$ for several hours at $T=650 \mathrm{~K}$. The $\mathrm{HNO}_{3} / \mathrm{H}_{2} \mathrm{O}_{2}$ treatment changed the reactivity of the surface significantly. Even at the highest temperature $T=798 \mathrm{~K}$, no $\mathrm{CH}_{3} \mathrm{OH}$ depletion was detected; i.e., the reaction rate dropped by more than a factor of $10^{3}$. This deactivation could not be influenced by washing the reactor with $\mathrm{H}_{2} \mathrm{O}_{2}$ or with an alkaline solution (like $\mathrm{NH}_{4} \mathrm{OH}$ ). The reactor was also passivated for the $\mathrm{C}_{2} \mathrm{H}_{5} \mathrm{OH}$ depletion reaction, i.e., the $\mathrm{C}_{2} \mathrm{H}_{5} \mathrm{OH}$ reacted in the same way as $\mathrm{CH}_{3} \mathrm{OH}$. The reactivity of the surface was increased by washing the reactor with $\mathrm{HCl}$. After a treatment with 0.1 molar $\mathrm{HCl}$ for about $0.75 \mathrm{~h}$ and rinsing with pure $\mathrm{H}_{2} \mathrm{O}$ for several hours, a rate constant for the $\mathrm{CH}_{3} \mathrm{OH}$ depletion of $k(750 \mathrm{~K}) \cong 0.04 \mathrm{~s}^{-1}$ was observed. This is more than a factor of 40 above the value obtained after the $\mathrm{HNO}_{3} / \mathrm{H}_{2} \mathrm{O}_{2}$ treatment. These observations clearly indicate that the methanol decomposition is strongly catalyzed by the surface of the reactor.

\section{Discussion}

The reaction

$$
\mathrm{CH}_{3} \mathrm{OH} \rightarrow \text { products }
$$

in supercritical water in a metal flow reactor proceeds at sufficient high (see below) concentrations in a first order reaction with an activation energy of $E_{\mathrm{A}}=167 \mathrm{~kJ} / \mathrm{mol}$. This small activation energy, compared to that of the decomposition in the gas phase, indicates that a molecular mechanism rather than a radical mechanism is occurring. The decomposition is surface catalized: At high $\mathrm{CH}_{3} \mathrm{OH}$ concentrations, which are sufficient to saturate the reactor surface with adsorbed methanol $\left(\mathrm{CH}_{3} \mathrm{OH}(\mathrm{ad})\right)$, the reaction appears to be first order in $\mathrm{CH}_{3} \mathrm{OH}$. At $\mathrm{CH}_{3} \mathrm{OH}$ concentrations below those necessary to saturate the surface, the reaction is no longer first order in $\mathrm{CH}_{3} \mathrm{OH}$ and appears to be much slower. In order to explain this significant lower $\mathrm{CH}_{3} \mathrm{OH}$ depletion rate, one has to assume that the methanol or one of the methanol decomposition products adsorbed at the wall is responsible for the $\mathrm{CH}_{3} \mathrm{OH}$ depletion rate. This could be described as a reaction $\mathrm{CH}_{3} \mathrm{OH}(\mathrm{ad})+\mathrm{CH}_{3} \mathrm{OH}(\mathrm{aq}) \rightarrow$ products. The $\mathrm{CH}_{3} \mathrm{OH}$ concentration profiles observed for high and low initial methanol concentrations show that a reaction product of the methanol decomposition is adsorbed on the wall and reacts with methanol.

These heterogeneous reaction indicated that the mechanism can not be as simple as the three reactions: 


$$
\mathrm{CH}_{3} \mathrm{OH} \rightarrow \mathrm{CH}_{2} \mathrm{O}+\mathrm{H}_{2}
$$

followed by:

$$
\mathrm{CH}_{2} \mathrm{OH}+\mathrm{H}_{2} \mathrm{O} \rightarrow \mathrm{CO}_{2}+\mathrm{H}_{2}
$$

and methane produced in the reaction:

$$
\mathrm{CH}_{3} \mathrm{OH}+\mathrm{H}_{2} \rightarrow \mathrm{CH}_{4}+\mathrm{H}_{2} \mathrm{O} .
$$

These three reactions are sufficient to explain the observed products but they are not sufficient to describe the kinetic behaviour of the system. The overall reaction:

$$
\mathrm{CH}_{3} \mathrm{OH}+\mathrm{H}_{2} \mathrm{O} \rightarrow \mathrm{CO}_{2}+3 \mathrm{H}_{2} \quad \Delta H(298 \mathrm{~K})=+50.6 \mathrm{~kJ} / \mathrm{mol}
$$

is endothermic and thus favored at higher temperatures as observed in the kinetic experiments.

The experiment, in which the $\mathrm{CH}_{3} \mathrm{OH}$ decomposition was suppressed completely by changing the reactor surface, via $\mathrm{HNO}_{3} / \mathrm{H}_{2} \mathrm{O}_{2}$ treatment, showed that the reaction is dominated by heterogeneous character. The change of the reactor surface would be explained by assuming that one of the alloy metals, which is responsible for the catalytic activity of the alloy, was specifically extracted from the surface. The $\mathrm{HCl}$ treatment renewed the surface by removing metal atoms unspecifically bringing back the catalytic activity.

Since the reaction (1) is a surface catalized reaction, it cannot simply be compared with data in other experiments unless the reactor surface and the pre-treatment of the reactor is described in detail.

The catalytic decomposition of methanol was studied in several publications [6,7, 12-15]. The main products observed by Hirth and Franck [7], when they studied the decomposition of methanol in dense supercritical water at $T=673 \mathrm{~K}$ and $T=773 \mathrm{~K}$ at $p=600$ bar, were $\mathrm{CO}_{2}, \mathrm{CH}_{4}$ and $\mathrm{H}_{2}$ in the gas phase after expansion. In the liquid phase only methanol was found. The decomposition kinetics in the non-corrosive nickel alloy reactor, however, was very slow. After one hour the percentage of decomposed methanol was $3.8 \%$. A temperature increase from $T=673 \mathrm{~K}$ to $T=773 \mathrm{~K}$ increased the methanol decomposition from 4.8 to $20.6 \%$. These data correspond to a rate $k_{1}(773 \mathrm{~K})=6.4 \times 10^{-5} \mathrm{~s}^{-1}$ and an activation energy of $E_{\mathrm{A}}=78.6 \mathrm{~kJ} / \mathrm{mol}$.

In more recent experiments [6] which were done in a nickel-based alloy (Inconal 625) reactor in the temperature range $673 \leq T / \mathrm{K} \leq 873$ at pressures from 25 to $45 \mathrm{MPa}$ the methanol residence times (methanol conversion $99.9 \%$ ) were in the range 3 to $100 \mathrm{~s}$. The main component of the product gas was hydrogen with smaller amounts of carbon dioxide, carbon monoxide and methane.

It can be concluded that the kinetic decomposition behaviour of methanol in supercritical water strongly depends on the surface whereas the reaction 
mechanism is less sensitive to the surface conditions. The decomposition rate varies for different reactor surfaces by two orders of magnitude whereas the reaction products are identical.

\section{Acknowledgement}

We are very grateful for the interest and stimulating discussions of Dr. F. Ben Wampler. We acknowledge the financial support of Los Alamos National Laboratory.

\section{References}

1. M. Buback, Angew. Chem. Int. Ed. Engl. 30 (1991) 641.

2. C. C. Miller, R. D. van Zee, and J. C. Stephenson, J. Chem. Phys. 114 (2001) 1214.

3. W. Hack, H. G. Wagner, and A. Wilms, Ber. Bunsenges. Phys. Chem. 92 (1988) 620.

4. C. Dombrowsky, A. Hoffmann, M. Klatt, and H. G. Wagner, Ber. Bunsenges. Phys. Chem. 95 (1991) 1685.

5. C. K. Westbrook and F. L. Dryer, Combust. Sci. Technol. 20 (1979) 125.

6. N. Boukis, V. Diem, W. Habicht, and E. Dinjus, Ind. Eng. Res. 42 (2003) 728.

7. T. Hirth and E. U. Franck, Ber. Bunsenges. Phys. Chem. 97 (1993) 1091.

8. T. Anita, K. Nakahara, K. Nagami, and O. Kajimoto, Tetrahedron Lett. 44 (2003) 1083.

9. J. W. Tester, P. A. Webley, and E. R. Holgate, Ind. Eng. Chem. Res. 32 (1993) 221.

10. P. C. Dell'Orco, B. R. Foy, J. M. Robinson, and S. J. Buelow, Haz. Waste 10 (1993) 221.

11. D. Masten, B. R. Foy, D. Harradine, and B. Dyer, J. Phys. Chem. 97 (1993) 8557.

12. D. T. Wickham, B. W. Logson, and S. W. Cowley, Am. Chem. Soc. Div. Fuel Chem. 31 (1986) 124.

13. B. Gao and J. Jing, J. Fuel Chem. Tech. 19 (1991) 77.

14. N. Kruse, M. Rebholz, and J. Block, Chem. Ing. Tech. 63 (1991) 615.

15. H. Shimizu and S. Takeoka, Nippon Kagaku Kaishi 4 (1986) 527. 